\title{
INVESTIGATION OF THE INFLUENCE OF CRYOPOWDERS "BROCCOLI" AND "LAMINARIA" ON QUALITY PARAMETERS OF CHEESE MASSES OF DIFFERENT FAT
}

\author{
Yuriy Hachak \\ Department of Technology of milk and milk products \\ Stepan Gzhytskyi National University of Veterinary Medicine and Biotechologies Lviv \\ 50 Pekarska str., Lviv, Ukraine, 79010 \\ gachak61@mail.ru \\ Natalya Slyvka \\ Department of Technology of milk and milk products \\ Stepan Gzhytskyi National University of Veterinary Medicine and Biotechologies Lviv \\ 50 Pekarska str., Lviv, Ukraine, 79010 \\ slyvkanat@ukr.net \\ Bogdan Gutyj \\ Department of Pharmacology and Toxicology \\ Stepan Gzhytskyi National University of Veterinary Medicine and Biotechologies Lviv \\ 50 Pekarska str., Lviv, Ukraine, 79010 \\ bvh@ukr.net \\ Jaroslava Vavrysevych \\ Department of Biological and General Chemistry \\ Stepan Gzhytskyi National University of Veterinary Medicine and Biotechologies Lviv \\ 50 Pekarska str., Lviv, Ukraine, 79010 \\ GutaZor@gmail.com \\ Alexander Sobolev \\ Department of Technology of poultry breeding and pig breeding products production \\ Bila Tserkva National Agrarian University \\ 8/1 Soborna area, Bila Tserkva, Kyivska oblast, Ukraine, 09111 \\ bvh@ukr.net

\section{Inna Bushueva} \\ Department of Clinical Pharmacy, Pharmacotherapy and Management and Economics of Pharmacy \\ Zaporizhzhya State Medical University \\ 26 Mayakovsky ave., Zaporozhye, Ukraine, 69035 \\ valery999@ukr.net \\ Tatyana Samura \\ Department of Clinical Pharmacology, Pharmacy, Pharmacotherapy and Cosmetology \\ Zaporizhzhya State Medical University \\ 26 Mayakovsky ave., Zaporozhye, Ukraine, 69035 \\ samuratetiana@ukr.net \\ Olena Paladiychuk \\ Department of Agricultural Animals and Zoohygiene \\ Vinnytsya National Agrarian University \\ 3 Soniachna str., Vinnytsya, Ukraine, 21000 \\ olenapaladiychuk@gmail.com
}




\author{
Liubov Savchuk \\ Department of normal and pathological morphology and physiology \\ State Agrarian and Engineering University in Podilia \\ 13 Shevchenka str., Kamianets-Podilskyi, Ukraine, 32300 \\ lyuba.savchuk.2015@ukr.net \\ Alina Pikhtirova \\ Department of Anatomy, Normal and Pathological Physiology \\ Sumy National Agrarian University \\ 160 H. Kondrateva str., Sumy, Ukraine, 40026 \\ alinca.sumy@gmail.com
}

\begin{abstract}
Crafty combination of cryopowders as bio-supplements to the "milk" base has great prospects in both bio-technological and social aspect. Main criteria at developing recipes of cheese masses were a search for optimal ratios of components for getting proper normative taste characteristics. In this connection, there is offered to study the influence of cryopowders "Broccoli" and "Laminaria" on quality parameters of cheese masses of the new generation, namely ones of the treating-prophylactic destination.

The analysis of organoleptic characteristics of salty cheese masses with the cryopowders "Laminaria" and "Broccoli" demonstrates that they have undergone no essential changes and correspond to normative requirements. Thus, the color of salt masses with the cryopowder "Laminaria" was light-grey with a green tint: at using the cryopowder "Broccoli" - grey with a yellow tint. The smell of cheese masses remained fresh, sour-milk. But the expressed smell of the added cryosupplement was felt in samples. The smack of experimental samples at adding the cryopowder "Broccoli" was more expressed. Their consistence was homogenous, delicate, paste-like.

The titrated acidity of experimental samples of salty cheese masses with the cryopowder "Laminaria" was $124-130{ }^{\circ} \mathrm{T}$, mass share of moisture $62-60 \%$ and mass share of dry substance $-40-38 \%$, and values of energetic value were 164 and $118 \mathrm{kcal} / 100 \mathrm{~g}$ of the product. The titrated acidity of experimental samples of salty cheese masses with the cryopowder "Broccoli" was $126-134{ }^{\circ} \mathrm{T}$, mass share of moisture 63-66 \% and mass share of dry substances - 34-37\%, and values of energetic value were 174 and $128 \mathrm{kcal} / 100 \mathrm{~g}$ of the product.

Cheese salty masses with using the cryopowders "Laminaria" and "Broccoli" as phytosupplements are products of the increased biological value, which production doesn't need the additional specialized equipment, is a potential source as to widening the assortment of products of the treating-prophylactic destination.

Keywords: cheese masses, cryopowders, sour-milk cheese, titrated acidity, energetic value.

\title{
1. Introduction
}

The problem of supplying the population with rational and balanced nutrition is today very urgent. Taking into account difficult ecological conditions, the modern human food ration must contain natural biologically active substances, able to increase the resistance of the organism, positively influence the metabolism [1,2]. The important direction in this aspect is to enrich them with vitamins, mineral and immune substances, especially ones of long storage $[3,4]$.

As it is known, there is no unitary recipe of high-quality nutrition. It depends on numerous factors: health condition of people, their age, professional specificity of the work, individual peculiarities of the organism of a person and many other [5].

The special importance among means of individual protection from the accumulation of toxic substances in the organism is given to compounds with radio-protective properties. In this aspect it is extremely promising to use natural biosupplements, substances of the natural origin without side effects on the organism. Cryopowders belong to such food substances [6, 7]. Their use both in pure (biosupplements) and in the composition of food products as biosupplements is urgent now. 
The crafty combination of cryopowders and milk base is promising, because there are obtained products, enriched with biologically active substances. Such products may be recommended in healthy nutrition for preventing a series of alimentary diseases. Cryopowders may also act as coloring agents and aromatizers, and also as technological supplements of the natural origin, improving consumption properties of food products. Cryopowders are useful for both children and adults $[8,9]$. They are obtained from pure natural raw materials (vegetables, berries, fruits, cereals) by the technology of cryogenic sublimation and extra-critical extraction by carbon dioxide $\left(\mathrm{CO}_{2}\right)$. Thus, concentrates of nutritive substances of these products that positively influence human health and longevity are created $[1,10]$.

Vegetable raw materials, that cryopowders are made of, are a source of antioxidants, such as carotenoids, tocopherols, phenols, flavonoids and tuning substances. This fact conditions their useful properties in fighting against free radicals that are a cause of a whole series of diseases [5].

Numerous studies, realized under conditions of the scientific laboratory of the department of milk and milk products technology have already considered the expedience of using separate specific biosupplements in the technology of fruit types of oils, fruit kefirs and yogurt $[1,5,9,10]$. According to the last scientific information, cryopowders are today most complete and most suitable for being used as one or another biosupplement in the composition of food products of the treating-prophylactic destination. Among them there are already acknowledged: "Bilberry", "artichoke", "Black ashberry", "Broccoli", "Laminaria", "Pumpkin" and many others. "Broccoli" and "Laminaria" interested us mostly among such diversity $[1,5,9,10]$.

In this connection, there is offered to elaborate the technology of cheese masses with the cryopowders "Broccoli" and "Laminaria" and investigation of their influence on quality parameters of ready products. It allows, for example, to improve taste characteristics, outlook, organoleptic properties.

\section{Materials and Methods}

The studies have been conducted under conditions of the scientific laboratory of the department of milk and milk products technology of the Lviv national university of veterinary medicine and biotechnologies, named after S.Z. Gzhytskyi and at production (Lviv, Ukraine). The cryopowders "Broccoli" and "Laminaria" have been used for them.

Cryopowder "Broccoli" (TC 9164-017-51764615-09) contains selenium, isothiocyanates, sulforaphane, indole-3-carbinol, glucosionates, vitamins C, A, U, group B, mineral substances: potassium, calcium, phosphorus, sodium, iron. Broccoli contains the cellular tissue of different types - cellulose, lignin, pectin. It helps to fight against constipations, facilitates the work of the intestine and protects it from oncological diseases. The special attention must be paid to broccoli also because of the increased content of bioactive compounds: sulforaphane, indole, isothiocyanates. Just they give broccoli its specific smell. Having penetrated the organism these compounds, stimulate production of enzymes, necessary for its detoxication and removal of toxins and carcinogens.

Cryopowder "Laminaria" (TC 9164-017-51764615-09) contains almost all irreplaceable amino acids, needed by the organism and very easily assimilated by it. Healthy properties of laminaria are conditioned by its composition. It contains food fibers, protein substances, beta-sitosterol, polysaturated fatty acids, type Omega-3, laminaria, algin acid, vitamins A, B1, B6, B12, C, D, panthotenic and folic acid; mineral substances: iodine, magnesium, bromine, calcium, potassium, sodium, manganese, copper, cobalt, boron. The unique complex of biologically active substances favors normalization of the function of the thyroid gland, central nervous, cardiovascular and respiratory systems, improvement of intellectual activity. Iodine improves assimilation of protein, phosphorus, potassium and iron, activates a series of enzymes, influences the work of follicles, menstrual cycle, decreases pathological manifestations of climax. Under the influence of iodine the blood viscosity is reduced, the tone of vessels and arterial pressure decrease. Phytohormones and vitamins activate the renewal of mucous membranes of the nose, oral cavity, intestine, female sexual organs. Algin acid allows to remove toxic metals and radionuclides from the organism. 
Two types of cheese were selected as a milk base - fatless and one with fat mass share $5 \%$, produced by the traditional way. The studies included the search and establishment of optimal ratios of components of the milk bases and cryopowder, elaboration of industrial recipes, investigation of organoleptic and physical-chemical properties of cheese products, estimation of their biological and food value.

The determining factor at adding biosupplements was preservation (maximally possible approximation) of normative characteristics of salty cheese masses.

The production technology of the offered cheese masses is presented on Fig. 1.

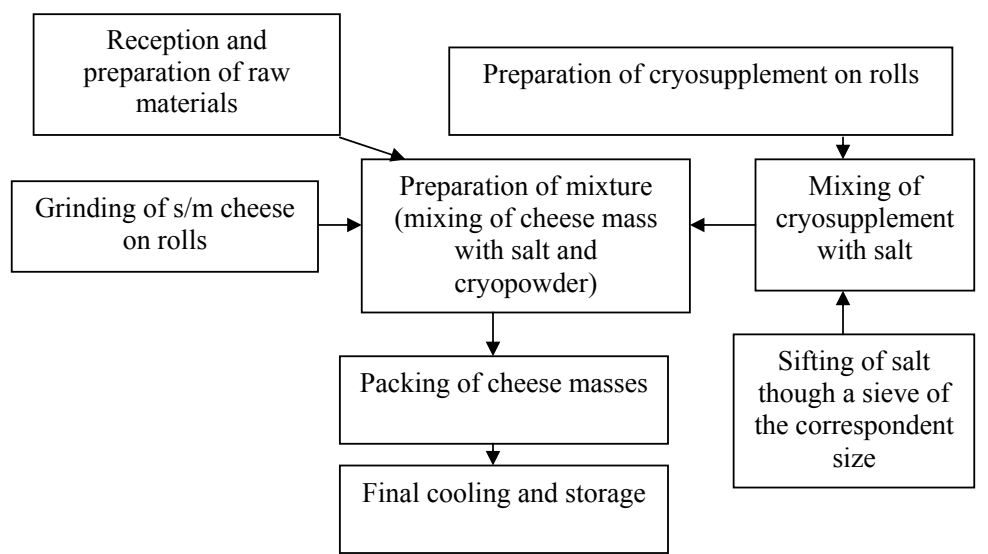

Fig. 1. Technological scheme of producing the cheese masses with the cryopowders "Broccoli" and "Laminaria"

Main criteria at elaborating recipes of the cheese masses were the search for optimal ratios of components for getting the proper normative taste characteristics, presented in Tables 1, 2. The recipe of the cheese masses was recalculated for industrial production for $1000 \mathrm{~kg}$ of ready products without taking into account losses.

There were prepared the salty (fat and fatless) cheese masses with the cryopowder "Laminaria" (Table 1). Sour-milk cheese, fatless or with fat mass share $5 \%$ was inset in the mixing machine in amounts 975,56 and 972,00 kg. At continuous mixing, there was added kitchen salt in amounts 16,44 and 15,78 kg and the cryopowder "Laminaria" - 8,00 and 12,22 kg. All was accurately mixed up and cooled to $4-6^{\circ} \mathrm{C}$ then stored till consumption.

Table 1

Recommended recipes of the salty cheese masses with adding the cryopowder "Laminaria"

\begin{tabular}{ccc}
\hline \multirow{2}{*}{ Composition of cheese masses } & \multicolumn{2}{c}{ Salty cheese masses } \\
\cline { 2 - 3 } & Fatless with cryopowder & Semi-fat with cryopowder \\
\hline Fatless cheese & 975,56 & - \\
Sour-milk cheese with fms 5\% & - & 972,00 \\
Kitchen salt & 16,44 & 15,78 \\
Cryopowder "Laminaria" & 8,00 & 12,22 \\
Totally & 1000 & 1000
\end{tabular}

There were prepared salty (fat and fatless) cheese masses with the cryopowder "Broccoli" (Table 2). Sour-milk cheese, fatless or with fat mass share $5 \%$ was inset in the mixing machine in amounts 974,66 and $970,00 \mathrm{~kg}$ respectively. At continuous mixing, there was added kitchen salt in amounts 14,59 and 15,78 kg and cryopowder "Broccoli" - 10,75 and 14,22 kg. All was accurately mixed up and cooled to $4-6{ }^{\circ} \mathrm{C}$ then stored till consumption. 
Table 2

Recommended recipes of salty cheese masses with adding the cryopowder "Broccoli"

\begin{tabular}{ccc}
\hline \multirow{2}{*}{ Composition of cheese masses } & \multicolumn{2}{c}{ Salty cheese masses } \\
\cline { 2 - 3 } Fatless cheese & Fatless with cryopowder & Semi-fat with cryopowder \\
\hline Sour-milk cheese with fms 5\% & 974,56 & - \\
Kitchen salt & - & 15,78 \\
Cryopowder "Broccoli" & 14,59 & 14,22 \\
Totally & 10,75 & 1000
\end{tabular}

The quality assessment of the studied cheese products was realized according to generally accepted methods, normative documents. SSU ISO 707-2002 «Milk and milk products». Instructions for taking of samples SSU ISO 5538:2004 «Milk and milk products. Taking of samples. Control over quality parameters».

The organoleptic parameters of the cheese mass: outlook, consistence, color were determined visually, taste and smell - organoleptically.

Point samples of the cheese mass were taken by a probe, by lowering it on the package bottom. Three point samples are separated: one from the center, other at the distance of $2-3 \mathrm{~cm}$ from the side wall of the package. The mass of a united sample is $500 \mathrm{~g}$, sample for the experiments 100 , and of products with stuffs $-150 \mathrm{~g}$. The united sample mass in the consumption package -100 or $150 \mathrm{~g}$.

Acidity determination of cheese masses by titration:

1. A batch of the cheese mass $(5 \mathrm{~g})$ was grinded in a porcelain mortar and rubbed, added with $50 \mathrm{ml}$ of distilled water, temperature $35-40{ }^{\circ} \mathrm{C}$.

2. Added with 3 drops of phenolphthalein and titrated by 0,1 alkaline solution to the light pink coloration that doesn't disappear during $1 \mathrm{~min}$.

3. The cheese mass acidity was calculated, the amount of alkali $(\mathrm{ml})$ for titration was multiplied by 20 . The difference between parallel calculations must not be more $4^{\circ} \mathrm{T}$.

Moisture determination of cheese masses by the express-method:

1. A porcelain cup with a glass stick and $20-25 \mathrm{~g}$ of sand was placed in a drying chamber for 1 hour. At temperature $102-105^{\circ} \mathrm{C}$.

2. $5 \mathrm{~g}$ of the cheese mass were weighted in a cup, mixed with sand and placed in the drying camber for $20 \mathrm{~min}$ at temperature $160-165^{\circ} \mathrm{C}$. Then weighed once more.

3. The moisture amount was calculated by the formula:

$$
\mathrm{B}=\frac{\mathrm{m}-\mathrm{m} 1}{5} \cdot 100,
$$

where B - moisture content in the cheese mass (\%); $\mathrm{m}$ - mass of the cup with sand and cheese before drying $(\mathrm{g}) ; \mathrm{m} 1$ - cup mass after drying $(\mathrm{g})$.

Mass share determination in cheese products.

The amount of fat in cheese products is determined using cream or milk fat-meters.

The technique of the fat mass share (fms) determination in the cream fat-meter:

1. Balance the fat-meter on technomechanical scales and weigh $5 \mathrm{~g}$ of the cheese mass on it.

2. Add the fat-meter with $5 \mathrm{ml}$ of water, $10 \mathrm{ml}$ of sulfuric acid and $1 \mathrm{ml}$ of isoamyl alcohol.

3. Close the fat-meter with a rubber bung, place in the water bath at temperature $65 \pm 2{ }^{\circ} \mathrm{C}$, periodically shaking to dissolution of protein.

Center it for $5 \mathrm{~min}$ with speed no less 1000 turns $/ \mathrm{min}$.

4. Place the fat-meter in the water bath for $5 \mathrm{~min}$ at temperature $65 \pm 2{ }^{\circ} \mathrm{C}$ bung down. 
5. Calculate the fat content on the scale. The fat-meter shows the fat content in the cheese masses in percent. The difference between parallel calculations of the microbiological control at producing sour-milk cheese must not be more $0,5 \%$.

\section{Results}

The assessment and determination of organoleptic characteristics of sour-milk cheese and cheese products is a main factor for establishing a price base for products, allowing to reveal and then to eliminate defects at their production.

For the analytic processing of the quality assessment results, the modern descriptive-profile method of sensor analysis was used that gave a possibility to determine the quality level of products and to make objective conclusions. The descriptive-profile method provides the use of 5-point system of the quality assessment of organoleptic parameters (descriptors) and profiling of quality parameters. The following descriptors were chosen: outlook, smell, taste, color, consistence.

New products were tested at the department of milk and milk products technology of LNUVMB, named after Gzhytskyi (Lviv, Ukraine) by the expert commission of six testers, found among teachers. 5-point assessment system was elaborated by the parameters: outlook, color, consistence, smell, taste (perfect -5 point, good -4 satisfactory -3 points, unsatisfactory -2 points, very bad -1 points). Based on the point assessment, there were chosen optimal doses of the cryopowders, presented in the recipes above. The cheese masses of the cryopowders "Laminaria" and "Broccoli" got 23 and 25 points, respectively.

in Table 3

Organoleptic parameters of the salty cheese masses with the cryopowders are presented

Table 3

Organoleptic parameters of the salty cheese masses with the cryopowders "Laminaria and "Broccoli"

\begin{tabular}{cccc}
\hline Name of cheese mass & Color, outlook & Smell and taste & Consistence \\
\hline $\begin{array}{c}\text { Cheese masses with stuffs } \\
\text { (TC;T) }\end{array}$ & $\begin{array}{c}\text { White with tint or color of } \\
\text { the stuff, even along the whole } \\
\text { mass }\end{array}$ & $\begin{array}{c}\text { Pure, sour-milk, with smell, } \\
\text { taste and fragrance of the stuff }\end{array}$ & $\begin{array}{c}\text { Homogenous, delicate, } \\
\text { moderately dense, with or } \\
\text { without stuff particles }\end{array}$ \\
$\begin{array}{c}\text { Salty cheese masses: fatless } \\
\text { and semi-fat with the } \\
\text { cryopowder "Laminaria" }\end{array}$ & Light-grey, green tint & $\begin{array}{c}\text { Fresh, salty, a bit sour, light, } \\
\text { smell and smack of laminaria }\end{array}$ & $\begin{array}{c}\text { Pasty, with particles of } \\
\text { cryopowder }\end{array}$ \\
$\begin{array}{c}\text { Salty cheese masses: fatless } \\
\text { and semi-fat with the } \\
\text { cryopowder "Broccoli" }\end{array}$ & $\begin{array}{c}\text { Fresh, salty, a bit sour, } \\
\text { distinctly expressed broccoli } \\
\text { smell and smack }\end{array}$ & $\begin{array}{c}\text { Pasty, with separate particles } \\
\text { of cryopowder }\end{array}$
\end{tabular}

The analysis of the organoleptic characteristics of the salty cheese masses with the cryopowders "Laminaria and "Broccoli" shows, that they haven't undergone any essential changes and mainly completely corresponded to normative requirements. Advantages of the experimental samples were the pleasant color, taste and smell of the introduced cryopowders "Laminaria" and "Broccoli". It allows to widen the assortment of cheese products, demanded by consumers.

One more important group of parameters for characterizing cheese masses is their physical-chemical parameters. The analysis of the numerical material of Table $\mathbf{4}$ testifies that an added cryopowder certainly influences also physical-chemical characteristics.

Thus, the titrated acidity of the experimental samples of the salty cheese masses with the cryopowder "Laminaria" was $124-130^{\circ} \mathrm{T}$, moisture ms $62-60 \%$ and DS - 40-38 \%, and energetic values were 164 and $118 \mathrm{kcal} / 100 \mathrm{~g}$ of the product. The titrated acidity of the experimental samples of the salty cheese masses with the cryopowder "Broccoli" had 126-134 ${ }^{\circ} \mathrm{T}$, ms $63-66 \%$ and DS $34-37 \%$, and energetic values were 174 and $128 \mathrm{kcal} / 100 \mathrm{~g}$ of the product.

It must be noted, that introduction of the cryopowders "Laminaria" and "Broccoli" doesn't essentially influence the physical-chemical characteristics of the experimental samples. 
Table 4

Main physical-chemical parameters of the cheese masses with the cryopowders "Laminaria" and "Broccoli"

\begin{tabular}{|c|c|c|c|c|c|}
\hline \multirow{2}{*}{ Name of cheese mass } & \multirow{2}{*}{ Acidity, ${ }^{\circ} \mathbf{T}$} & \multicolumn{3}{|c|}{ Mass share, $\%$} & \multirow{2}{*}{$\begin{array}{l}\text { Energetic value } \\
\quad \text { (kcal/100 g) }\end{array}$} \\
\hline & & moisture & GE & fat & \\
\hline Normative values of cheese masses & $120-140$ & $60-70$ & - & Fatless; 4-6 & $120-180$ \\
\hline $\begin{array}{l}\text { Salty cheese masses: fatless and semi-fat } \\
\text { with the cryopowder "Laminaria" }\end{array}$ & $130 / 124$ & $62 / 60$ & $38 / 40$ & Fatless; 4,2 & $118 / 164$ \\
\hline $\begin{array}{l}\text { Salty cheese masses: fatless and semi-fat } \\
\text { with the cryopowder "Broccoli" }\end{array}$ & $134 / 126$ & $66 / 63$ & $34 / 37$ & Fatless; 4,6 & $128 / 174$ \\
\hline
\end{tabular}

During the conducted studies there has been observed a regularity that the more mass share of fat of the ready product, the less titrated acidity and moisture mass share in the cheese masses is. But these parameters didn't exceed limits of the normative values.

The energetic value of the developed products grew due to the chemical composition of cryopowders, especially vitamins.

Thus, as a result of two series of experiments, it has been proved the expedience of using the offered cryopowders "Laminaria" and "Broccoli" in the technology of the cheese masses of different acidity. The experimental samples widen the assortment of milk products of the treating-prophylactic destination.

\section{Conclusions}

The use of the cryopowders "Laminaria" and "Broccoli" as phytosupplements in the technology of the cheese masses of different acidity influences their outlook, color of products, is reflected on their composition, while other technological parameters are within the normative requirements at both preparation and storage. The cheese masses with the cryopowders "Laminaria" and "Broccoli", used as phytosupplements, are products of the increased biological value, which production doesn't need the additional specialized equipment, and a potential source of widening the native assortment of the treating-prophylactic destination.

So, the use of vegetable components in the technological process of cheese masses is important from both theoretical and practical points of view. Experiments in this direction are promising and interesting, contain practical recommendations for production, and result in outputting the new product, useful for potential consumers.

\section{References}

[1] Gutyj, B., Hachak, Y., Vavrysevych, J., Nagovska, V. (2017). The influence of cryopowder “Garbuz" on the technology of curds of different fat content. Eastern-European Journal of Enterprise Technologies, 2 (10 (86)), 20-24. doi: https://doi.org/10.15587/1729-4061.2017.98194

[2] Hoiko, I. Yu. (2016). Rozroblennia fitokompozytsiy dlia vyrobnytstva funktsionalnykh kyslomolochnykh syriv. Problemy starenija i dolgoletiya, 25 (2), 273-279.

[3] Lisovska, Yu., Puneiko, O. (2018). Rozrobka retseptur molochnykh produktiv LPN iz krioporoshkom iz moreproduktiv. Dni studentskoi nauky u LNUVM ta BT imeni S. Z. Hzhytskoho: Materialy studentskoi konferentsiyi. Lviv, 110-111.

[4] Barbano, D. M., Margolies, B. (2016). 0566 Critical factors for evaluation of cheese yield performance and fat loss in large cheese factories. Journal of Animal Science, 94 (suppl_5), 269-270. doi: https:// doi.org/10.2527/jam2016-0566

[5] Hachak, Y., Gutyj, B., Bilyk, O., Nagovska, V., Mykhaylytska, O. (2018). Effect of the cryopowder "Amaranth" on the technology of meolten cheese. Eastern-European Journal of Enterprise Technologies, 1 (11 (91)), 10-15. doi: https://doi.org/10.15587/1729-4061.2018.120879

[6] Mamone, G., Picariello, G., Caira, S., Addeo, F., Ferranti, P. (2009). Analysis of food proteins and peptides by mass spectrometry-based techniques. Journal of Chromatography A, 1216 (43), 7130-7142. doi: https://doi.org/10.1016/j.chroma.2009.07.052 
[7] Boichak, Ya., Koberniuk, V., Petryk, L. (2018). Novi vydy i formy biodobavok v tekhnolohiyi molochnykh produktiv LPN. Dni studentskoi nauky u LNUVM ta BT imeni S.Z Hzhytskoho: Materialy studentskoi konferentsii. Lviv, 79-80.

[8] Turchyn, I., Zalensky, M., Voychishin, A. (2018). Development of technology of cereal past with combined composition. Scientific Messenger of LNU of Veterinary Medicine and Biotechnologies, 20 (85), 24-28. doi: https://doi.org/10.15421/nvlvet8505

[9] Nagovska, V., Hachak, Y., Gutyj, B., Bilyk, O., Slyvka, N. (2018). Influence of wheat bran on quality indicators of a sour milk beverage. Eastern-European Journal of Enterprise Technologies, 4 (11 (94)), 28-35. doi: https://doi.org/10.15587/1729-4061.2018.140093

[10] Simakhina, H. O. (2011). Biolohichna tsinnist ta funktsionalna diya komponentiv krioporoshkiv tsukrovykh buriakiv. Tsukor Ukrainy, 6-7.

\title{
PROBATION OF THE APPARATUS FOR LOW-TEMPERATE PROCESSING OF MEAT CULINARY PRODUCTS BY IR-RADIATION
}

\author{
Andrii Zahorulko \\ Department of Processes, Devices and Automation of Food Production \\ Kharkiv State University of Food Technology and Trade \\ 333 Klochkivska str., Kharkiv, Ukraine, 61051 \\ zagorulkoAN@hduht.edu.ua \\ Aleksey Zagorulko \\ Department of Processes, Devices and Automation of Food Production \\ Kharkiv State University of Food Technology and Trade \\ 333 Klochkivska str., Kharkiv, Ukraine, 61051 \\ zagorulko@hduht.edu.ua \\ Maryna Yancheva \\ Department of Meat Technology \\ Kharkiv State University of Food Technology and Trade \\ 333 Klochkivska str., Kharkiv, Ukraine, 61051 \\ ya.marina11@gmail.com \\ Maksym Serik \\ Department of Chemistry, Microbiology and Food Hygiene \\ Kharkiv State University of Food Technology and Trade \\ Director of the Educational and Scientific Institute of Food Technology and Business \\ of Kharkiv State University of Food Technology and Trade \\ 333 Klochkivska str., Kharkiv, Ukraine, 61051 \\ serik_m@hduht.edu.ua

\section{Sergei Sabadash} \\ Department of Chemistry, Microbiology and Food Hygiene \\ Kharkiv State University of Food Technology and Trade \\ Director of the Educational and Scientific Institute of Food Technology and Business of Kharkiv \\ State University of Food Technology and Trade \\ 160 G. Kondratiev str., Sumy, Ukraine, 40021 \\ s.v.sabadash@ukr.net
}

